\title{
PERAN PIKIRAN BAWAH SADAR (SUBCONSCIOUS MIND) DALAM PROSES MENULIS DAN PEMBELAJARAN NARATIF
}

\section{ROLE OF SUBCONSCIOUS MIND IN THE PROCESS OF WRITING AND NARRATIVE LEARNING}

\author{
Zainurrahman \\ Prodi Pendidikan Bahasa dan Sastra Inggris, STKIP Kie Raha Temate \\ Jalan Raya STKIP, Sasa, Temate Selatan
}

\begin{abstract}
Abstrak
Pikiran bawah sadar manusia adalah pikiran yang kaya akan motivasi, kreatifitas, dan emosi. Seandainya setiap orang mampu mengaksesnya, maka setiap orang dapat memanfaatkan kekayaan pikiran bawah sadar dalam berbagai kebutuhan dan tujuan, tidak terkecuali tujuan pendidikan dan pembelajaran. Salah satu model pembelajaran yang melibatkan aktivitas akses pikiran bawah sadar adalah hypnoteaching. Hypnoteaching melibatkan 5 unsur kompleks, yakni quantum teachinglearning, powerteaching, neuro-linguistic programming, accelarated learning, dan hypnosis. Hal ini menunjukkan bahwa tanpa penguasaan salah satu dari kelima unsur ini, maka model pembelajaran tersebut tidak maksimal. Di antara kelima unsur ini, pelibatan aktivitas pikiran bawah sadar terletak pada unsur terakhir, yakni hipnosis. Dalam pembelajaran atau proses menulis naratif, pikiran bawah sadar memainkan peranan yang sangat penting. Salah satu fungsi yang diperankan oleh pikiran bawah sadar dalam menulis naratif adalah menggali informasi atau data yang tersimpan di dalamnya kemudian menampilkannya dalam bentuk visual (mental image) dan memberikan peluang pada kita untuk berkreasi dengan informasi-informasi tersebut, menyusunnya menjadi sebuah cerita atau naratif. Tulisan ini akan menampilkan bagaimana hipnosis murni (bukan hypnoteaching) dapat digunakan dalam pembelajaran atau proses penulisan naratif.
\end{abstract}

Kata kunci: pikiran, hipnosis, naratif

\begin{abstract}
Human subconscious mind is rich of motivation, creativity, and emotion. If everyone is able to access it, then everyone can utilize their subconscious treasures for various needs and purposes, including education and learning purposes. One of the learning models which includes accessing subconscious mind is hypnoteaching. Hypnoteaching includes 5 complex elements; they are quantum teachinglearning, power teaching, neuro-linguistic programming, accelerated learning, and hypnosis. This shows that without one of these five elements, then the application of hypnoteaching learning model is not effective. Among these five elements, hypnosis is the one part which touches the subconscious mind. In narrative writing (and learning) process, subconscious mind plays a very important role. One of the roles is digging the information or data stored in it, then displaying it visually (mental image) and giving us chance to create and structure them to be a story or a narrative. This article provides information how pure hypnosis (not hypnoteaching)can be utilized in the narrative learning or writing process.
\end{abstract}

Keywords: mind, hypnosis, narrative

\section{Pendahuluan}

Pikiran manusia terdiri atas dua bagian, yakni pikiran sadar (conscious mind) dan pikiran bawah sadar (subconscious mind). Sebagaimana para pembaca akan temukan melalui tulisan ini, segala perilaku manusia dalam keseharian sebagian 
besar dipengaruhi oleh pikiran bawah sadar. Segala bentuk aktivitas kita sehari-hari, termasuk menulis, mendapatkan porsi pengaruh bawah sadar yang cukup besar. Menurut Gunawan (2012:18) , pengaruh pikiran bawah sadar terhadap diri kita adalah $88 \%$ sedangkan untuk pikiran sadar pengaruhnya $12 \%$; selanjutnya, pikiran sadar dan pikiran bawah sadar sebenarnya saling mempengaruhi dan bekerja secara paralel dengan kecepatan yang sangat tinggi.

Melihat persentase pengaruh pikiran bawah sadar yang begitu besar ini, kita mungkin akan bertanya-tanya fungsi apa sajakah yang dilaksanakan oleh pikiran bawah sadar ini dalam kehidupan kita, dalam keseharian kita. Seorang pakar di bidang teknologi pikiran menjelaskan fungsi pikiran bawah sadar ini dan salah satu fungsi yang diutarakan adalah fungsi kreativitas (Gunawan, 2012). Fungsi kreativitas dari pikiran bawah sadar itu yang akan dibahas dalam tulisan ini.

Proses penulisan naratif seperti cerpen, novel, dan sebagainya, merupakan proses menulis fiksi yang menuntut kreatifitas yang tinggi. Dengan demikian, memahami pikiran bawah sadar yang berperan menjalankan fungsi kreatifitas berarti memahami bagaimana memaksimalkan kreativitas itu sendiri.

Berbicara tentang pikiran bawah sadar, kita akan diarahkan pada suatu kata yang secara umum masih belum dipahami secara benar oleh sebagian besar masyarakat, yakni hipnosis. Menurut Yan Nurindra, Hipnosis itu sendiri adalah seni dalam menyampaikan pesan, atau komunikasi persuasif, ke "pusat motivasi". (Nurindra, 2008). Yang dimaksud dengan "pusat motivasi" oleh Yan Nurindra itu adalah pikiran bawah sadar. Definisi hipnosis menurut Gunawan (2012:3) adalah suatu kondisi di mana perhatian menjadi sangat terpusat sehingga tingkat sugestibilitas meningkat sangat tinggi. Sementara itu, di dalam dunia pendidikan dan pengajaran, istilah hipnosis ini kemudian dikembangkan menjadi hypnoteaching; katakanlah, sebagai aplikasi hipnosis di dalam proses belajar mengajar.

Hypnoteaching itu sendiri adalah suatu sistem yang kompleks. Selain itu, pergeseran makna telah terjadi antara hypnosis dan hypnoteaching. Abdul Latif (2013) mendefinisikan hypnoteaching sebagai seni berkomunikasi dalam memberikan sugesti positif kepada siswa agar siswa menjadi lebih baik atau lebih cerdas. Abdul latif (dengan merujuk pada Hajar, 2012) bahwa hypnoteaching merupakan model pembelajaran yang menggabungkan quantum learning, accelarated learning, power teaching, neuro-linguistic programming, dan hypnosis. Hal ini menunjukkan kompleksitas hypnoteaching yang terkesan tidak sederhana.

Hypnoteaching, sebagaimana istilah tersebut mengisyaratkan, menempatkan guru pada posisi utama sebagai fasilitator dan siswa pada posisi kedua sebagai klien, atau di dalam istilah hipnosis disebut suyet. Sebagai fasilitator, guru akan melakukan mediasi yang besifat membimbing kepada siswa agar memasuki kondisi bawah sadar yang di dalam hipnosis disebut sebagai kondisi trance. Meskipun demikian, trance pada hypnoteaching dan hipnosis lainnya seperti hipnosis panggung dan clinical hypnosis atau hypnotherapy (aplikasi hipnosis dalam urusan kesehatan) terdapat perbedaan. Pada hipnosis, kondisi trance diisyaratkan dengan keadaan serupa "tidur" meskipun sebenarnya suyet tidak tertidur pulas, melainkan berada pada alam relaksasi yang dalam, sedangkan dalam hypnoteaching para siswa yang adalah suyet atau subjek mengalami trance dengan mata terbuka; ini barangkali yang disebut dengan waking hypnosis, atau hipnosis dengan mata terbuka.Hypnoteaching sendiri masih digolongkan sebagai pseudosains dikarenakan oleh kurangnya referensi saintifik yang membahasnya (Abdul Latif, 2013).

Inti dari hipnosis, hipnosis panggung, hipnosis klinis, dan hypnoteaching, adalah akses terhadap pikiran bawah sadar. Memandu suyet 
hingga memasuki kondisi trance sehingga suyet mampu menggali dan memanfaatkan informasi yang terkandung di dalam pikiran bawah sadarnya. Melalui tulisan ini, penulis akan memaparkan bagaimana peran pikiran bawah sadar dalam proses menulis naratif. Perbedaan yang mungkin terdapat antara tulisan ini dengan tulisan ilmiah lain yang membahas hal yang sama terletak pada sudut pandang dan prosedur. Jika pada umumnya hypnoteaching menekankan peran guru sebagai penyampai pesan, pemberi sugesti, maka dalam tulisan ini penulis lebih menekankan aspek siswa sebagai individu yang kreatif dan potensial. Hal ini didasarkan pada prinsip dasar hipnosis, bahwa sesunggunya seluruh hipnosis pada dasarnya adalah selfhypnosis (menghipnosis diri sendiri).

Tulisan ini dibagi menjadi tiga bagian. Pada bagian pertama, penulis memaparkan pikiran bawah sadar dan kondisi trance. Adapun bagian kedua penulis memaparkan sekelumit teori naratif. Sedangkan pada bagian terakhir, penulis memaparkan formulasi prosedur hipnosis yang dapat digunakan dalam pengajaran menulis naratif.

\subsection{Pikiran Bawah Sadar dan Kondisi Trance}

\subsubsection{Pikiran Bawah Sadar}

Pikiran bawah sadar, subconscious mind, sebagaimana yang telah dijelaskan sebelumnya, adalah salah satu dari dua jenis pikiran yang dimiliki oleh setiap ummat manusia dan memiliki porsi besar dalam melatarbelakangi prilaku hidup dibandingkan dengan pikiran sadar atau conscious mind. Kemudian, yang dimaksud dengan kondisi trance (trance state) merupakan keadaan dimana seseorang menjalankan aktivitas berbasis pikiran bawah sadar itu sendiri. Istilah lain dari kondisi ini adalah kondisi hipnosis (hypnosis state) dan ini sebenarnya terjadi pada kita puluhan bahkan ratusan kali dalam keseharian kita.

Istilah bawah sadar, hipnosis, trance, barangkali merupakan istilah yang cukup baru bagi sebagian masyarakat. Seringkali pikiran bawah sadar diartikulasikan sebagai alam bawah sadar yang berkonotasi pada "ketidaksadaran" yang sebenarnya merupakan domain lain dari hipnosis itu sendiri. Ketidaksadaran (unconsciousness) jelas berbeda dengan bawah sadar. Istilah bawah sadar itu sendiri pada hakikatnya merupakan representasi mekanisme pikiran di balik tindakan. Akan tetapi, istilah pikiran bawah sadar ini di dalam kajian psikoanalisa Sigmund Freud disebut unconscious mind. Ada baiknya jika perbedaan istilah ini tidak dipersoalkan, meskipun secara harafiah kedua kata ini (subconscious dan unconscious) sebenarnya berbeda.

Pikiran bawah sadar dapat dianggap sebagai media penyimpanan data (virtual storage) yang mana data tersebut diakses dan dijalankan oleh manusia dalam kesehariannya. Freud menggambarkan pikiran bawah sadar ini seperti bawahan dari sebuah gunung es yang ukurannya lebih besar dari atasannya (pikiran sadar). Pada pikiran bawah sadar inilah proses-proses mental terjadi, yang berdampak pada tindakan atau perilaku. Misalnya ketika kita haus maka secara otomatis kita akan mencari sesuatu untuk diminum (McLeod, 2015). Tindakan atau perilaku mencari minum ini bukan berasal dari pertimbangan analitik seperti mencegah dehidrasi (ini adalah domain pikiran sadar).

Sebagaimana yang telah disebutkan sebelumnya, bahwasanya pikiran bawah sadar menyimpan informasi atau data. Setiap informasi yang tersimpan dalam pikiran bawah sadar ini pada dasarnya melewati pikiran sadar terlebih dahulu. Dalam hal ini, pikiran sadar manusia senantiasa melakukan filterisasi informasi atau data sebelum informasi tersebut masuk atau terekam ke dalam pikiran bawah sadar. Setelah informasi atau data, atau program, terekam di dalam pikiran bawah sadar, pada kondisi tertentu, akan tereksekusi atau dijalankan. Kondisi inilah yang kita sebut kondisi trance. Dalam kondisi trance, program yang telah "terinstal" di dalam 
pikiran bawah sadar merupakan dasar dari tindakan. Dalam hal ini, menurut Bargh dan Morsella, pikiran sadar kemudian akan memberikan makna setelah terjadi tindakan yang dasarnya adalah program bawah sadar (2008:77).

Di balik pikiran bawah sadar sebenarnya terdapat wilayah lain yang disebut dengan nilai dasar. Nilai dasar ini merupakan informasi atau data dasar yang tertanam sejak kecil seperti ajaran agama, sistim kepercayaan, ajaran moral, minat, dan sebagainya. Wilayah ini bertugas sebagai "penjaga kedua" pikiran bawah sadar. Data-data awal yang tertanam pada wilayah ini berperan untuk menolak informasi-informasi yang dianggap destruktif yang berhasil melalui pikiran sadar. Misalnya, ketika seseorang dihipnotis (dan berhasil dihipnotis) kemudian disugesti untuk melakukan hal-hal yang bertentangan dengan nilai dasar yang dimilikinya, maka orang itu akan keluar dari kondisi trance dan pikiran sadarnya akan segera aktif untuk menolak informasi dari sugesti tersebut.

Penetrasi informasi ke dalam pikiran bawah sadar dapat terjadi dalam beberapa cara, di antaranya adalah secara persuasif dan secara otoritatif. Yang dimaksud dengan cara persuasif adalah cara sebuah informasi atau sugesti diberikan kepada seseorang dalam bentuk saran sedangkan cara otoritatif lebih berbentuk pada perintah.

Di dalam hypnoteaching misalnya, informasi atau sugesti dari guru pada para siswa lebih bersifat otoritatif, mengingat guru merupakan tokoh yang dipandang memiliki otoritas. Selain guru, tokoh lain sebut saja orang tua, ulama, pendeta, hakim, dan sebagainya, mereka dipandang memiliki otoritas dan oleh karenanya informasi yang diberikan akan langsung masuk dan terprogram di dalam pikiran bawah sadar. Ketika seseorang berada pada kondisi tertentu, program itu akan dijalankan. Misalnya seorang muslim yang hendak shalat akan mengambil air wudhu, dan ketika air wudhunya batal karena satu dan lain penyebab, maka secara otomatis orang ini akan kembali mengambil air wudhu.

Contoh untuk penetrasi informasi secara persuasif dapat dilihat ketika seorang terapis hipnosis klinis meminta atau mengajak pasien atau suyet untuk berimajinasi, membayangkan, merasakan, atau melakukan hal tertentu. Pasien atau suyet tersebut menerima informasi itu berdasarkan kehendak kesembuhan yang membutuhkan kerjasama agar dapat terwujud pada dirinya.

Sebenarnya ada cara ketiga yang tidak bersifat persuasif maupun otoritatif, yakni informasi atau data yang masuk ke pikiran bawah sadar yang disebabkan oleh pengalaman traumatik atau kejadian di luar kesengajaan yang lain. Contohnya saat seorang siswa begitu gugup dan takut ketika berdiri di hadapan kelas karena pernah mengalami kejadian "memalukan" ketika berada di depan kelas. Siswa ini memberikan makna bahwa "berdiri di depan kelas dengan tujuan apapun merupakan kejadian yang mempermalukan diri" dan ini dikategorikan sebagai fobia.

Melihat contoh ini, maka sebenarnya masuk, terprogram, dan jalannya program bawah sadar merupakan kejadian sehari-hari yang dialami oleh manusia. Peristiwa fokus belajar di kelas, mendengarkan ceramah, membaca buku, menonton tayangan televisi, merupakan peristiwa hipnosis yang kita alami dalam keseharian kita. Aktivitas pikiran bawah sadar terjadi dari waktu ke waktu di dalam keseharian kita.

Pikiran bawah sadar juga dapat diakses dan diaktifkan dengan sengaja untuk tujuan tertentu. Aktivasi pikiran bawah sadar ini dilakukan dengan cara menurunkan gelombang otak, atau menurunkan frekuensi kerja pikiran sadar sehingga suyet memasuki kondisi trance yang mana akan dijelaskan pada bagian berikut. Pada bagian berikutnya, penulis memaparkan perihal kondisi trance dan prosedur standar yang dapat dijalankan untuk memasuki kondisi trance dengan sengaja untuk kepentingan pembelajaran. 
Prosedur ini mungkin berbeda dengan prosedur hypnoteaching karena prosedur yang digunakan adalah prosedur murni hipnosis yang dirumuskan untuk kepentingan penulisan naratif.

\subsubsection{Kondisi Trance}

Kondisi trance adalah kondisi turunnya frekuensi gelombang otak, berkurangnya aktivitas pikiran sadar, sehingga aktifnya pikiran bawah sadar. Kondisi trance yang kita alami sehari-hari contohnya adalah ketika membaca sebuah novel dengan begitu serius, menikmati tayangan televisi hingga mempengaruhi emosi, terfokus pada suatu hal dan mengabaikan hal lain, ketika berdo'a, dan sebagainya. Pada kondisi-kond is $i$ tersebut, aktivitas pikiran sadar kita menurun. Jika kita ingin dengan sengaja memasuki atau memasukkan seseorang ke kondisi trance, kita juga harus dengan sengaja menurunkan aktivitas gelombang otaknya. Untuk itu, perlu kiranya kita memahami mengapa kita harus mengurangi aktivitas pikiran sadar untuk bisa mengaktifkan pikiran bawah sadar.

Pikiran sadar (conscious mind) memiliki beberapa fungsi dan salah satunya adalah fungsi analisis kritis (Gunawan, 2012). Melalui fungsi ini, pikiran sadar berperan untuk menganalisis setiap informasi yang masuk, mempertimbangkan apakah diterima atau ditolak, dan membandingkan informasi yang masuk dengan informasi yang sudah ada di dalam pikiran bawah sadar (bertentangan atau sejalan dengan informasi atau data awal atau nilai dasar), jika informasi yang masuk sejalan dengan informasi yang sudah ada, informasi tersebut akan diteruskan ke pikiran bawah sadar (wilayah penjagaan ini disebut critical area). Sementara itu jika informasi yang masuk bertentangan dengan informasi yang sudah ada, informasi tersebut ditolak.

Melihat fungsi dan peran yang dijalankan oleh pikiran sadar atau pikiran analitik ini, maka tidak berlebihan jika kita mengatakan bahwa pikiran sadar adalah penjaga gerbang pikiran bawah sadar. Pikiran bawah sadar harus dijaga dengan ketat oleh pikiran sadar agar informasi atau program yang destruktif tidak dapat masuk ke pikiran bawah sadar. Meskipun demikian, pikiran sadar ini juga dapat lengah dalam melaksanakan tugasnya. Ketika pikiran sadar lengah, kegiatan analisis-nya akan terhenti sejenak dan gerbang pikiran bawah sadar pun terbuka dan informasi apapun dapat masuk ke pikiran bawah sadar. Akan tetapi, informasi yang sudah berhasil masuk belum langsung terekam secara permanen, karena masih ada nilai dasar yang akan melakukan cross-check. Jika informas i itu bertentangan dengan nilai dasar, pikiran bawah sadar akan memberikan sinyal kepada pikiran sadar sehingga pikiran sadar dapat aktif kembali melakukan penjagaan, atau kita sebut dengan waspada.

Pikiran sadar kita senantiasa bekerja dari waktu ke waktu, menganalisa, mempertimbangkan, membandingkan, memutuskan, sehingga kita senantiasa berada pada posisi mawas diri atau bersikap kritis (berada pada posisi beta) (untuk fungsi pikiran sadar secara lengkap lihat Gunawan, 2012). Selama kita berada pada posisi ini, kita tidak akan mengalami trance. Oleh karena itu, untuk bisa memasuki kondisi trance, maka kita harus menurunkan aktivitas kerja pikiran sadar, dan itu bisa kita lakukan dengan proses relaksasi (dengan sengaja mengistrahatkan pikiran sadar untuk bersikap kritis setiap informasi yang masuk) (berada pada posisi alfa dan tetha). Ada berbagai macam cara yang bisa kita gunakan untuk memasuki kondisi trance ini. Namun apapun caranya, hanya ada satu istilah yang digunakan secara umum, yakni induksi.

Di dalam kondisi trance inilah kita berada pada wilayah pikiran bawah sadar. Kondisi trance itu sendiri adalah kondisi relaksasi total, ketika kita menjadi sangat sensitif terhadap informasi yang masuk, setiap indera menjadi sangat peka, karena pikiran sadar atau pikiran analitik kita sedang 'beristirahat'. Inilah saat 
ketika kita mampu merasakan berbagai sensasi, emosi, imajinasi, yang memberikan pengaruh pada fisik seperti merasakan apa yang dibayangkan, atau dipikirkan oleh pikiran bawah sadar (ini disebut fenomena psikosomatis).

Ketika kita berada di dalam kondisi trance, pikiran bawah sadar cenderung menerjemahkan informasi dalam bentuk visual. Ini sama dengan ketika kita membayangkan atau mengingat-ingat suatu tempat, sambil menutup mata, kita seolaholah melihat apa yang kita bayangkan atau apa yang kita ingat. Ini merupakan produk dari aktivitas pikiran bawah sadar kita (produk visual pikiran bawah sadar ini kita sebut imajinasi, dan kata imajinasi/image ini pada dasarnya berarti gambar). Dan inilah salah satu alasan mengapa kita atau suyet perlu berada di dalam kondisi trance agar bisa berimajinasi untuk menulis fiksi.

Dengan kondisi menguntungkan seperti ini, begitu banyak informasi yang dapat kita tuangkan ke dalam narasi fiksi yang kita tulis. Informasiinformasi itu siap dituangkan dan tugas kita atau suyet adalah merancang struktur bahasa yang menarik dalam menuangkan informasi tersebut.

Sampai pada titik ini, kita sudah memahami kerja pikiran bawah sadar dan juga memahami kondisi trance serta bagaimana cara agar bisa memasuki kondisi trance atau induksi. Prosedur induksi akan dibahas lebih lanjut pada bagian ketiga. Kini kita akan membahas sekelumit teori naratif yang akan dihubungkan dengan kerja pikiran bawah sadar dan kondisi trance yang sudah kita bahas.

\section{Teori Naratif}

Istilah naratif dapat kita pikirkan sebagai cerita. Hal ini berdasarkan pada etimologi naratif yang menurut Alwasilah sebagai derivasi dari kata to narrate yang berarti menceritakan (2005:119). Jika kita berbicara tentang cerita, terdapat setidaknya dua jenis besar dari cerita, yakni cerita faktual dan cerita fiktif. Cerita faktual adalah cerita yang dibangun dari realita sedangkan cerita fiktif adalah cerita yang dibangun dari imajinasi (Evans, 2000).

Sebuah naratif setidaknya memiliki lima element di dalamnya, yakni orientasi (karakter cerita, tempat, dan waktu), komplikasi (konflik, kejadian), evaluasi (alasan dari konflik), resolusi (solusi dari komplikasi), dan koda (makna cerita dan pesan moral) (Feez dan Joyce, 2003; Labov, 1997).

Melihat deskripsi singkat arti naratif serta elemen yang membangunnya, maka keseluruhan naratif adalah informasi-informasi yang sebenarnya terekam di dalam pikiran bawah sadar (memory adalah salah satu jenis informasi yang tersimpan di dalam pikiran bawah sadar). Ini juga berkaitan dengan makna kata cerita yang merupakan kejadian yang sudah berlalu. Setiap kejadian menimbulkan pengalaman, memberikan informasi, dan semua ini tersimpan dalam pikiran bawah sadar. Dan ketika menulis sebuahnaratif, misalnya naratif faktual, berupaya mengingat kembali apa yang sudah terjadi merupakan aktivitas pikiran bawah sadar. Mengapa sehingga berbagai informasi krusial tidak dapat terungkap jika kita tidak memiliki diary atau catatan kejadian? Karena kita tidak melakukan ini dalam kondisi trance. Ketika berada dalam kondisi trance, kita bahkan bisa mengingat sesuatu yang sudah dilupakan oleh pikiran sadar. Misalnya, kita mengingat kejadian di waktu kecil, dalam kondisi trance kita mendapatkan kesan visual yang jelas tentang kejadian waktu itu. Ini di dalam proses hipnoterapi disebut dengan regresi usia (age regression) dan ini sudah dibuktikan oleh banyak pakar (lihat Gunawan, 2012).

Bagaimana jika kita menulis atau mengajarkan menulis naratif fiksi dimana kejadian nyatanya tidak pernah ada? Ini sebenarnya sama sekali tidak menjadi kendala bagi kita. Apapun yang terdapat di dalam pikiran bawah sadar kita dapat kita manfaatkan. Pikiran bawah sadar memiliki daya imajinasi yang tinggi. Melalui informasi-informasi yang sudah ada, maka imajinasi akan terbentuk sesuai dengan 
kehendak suyet atau arahan seorang guru atau fasilitator. Kita bisa membentuk informasi baru dari informasi lama yang sudah ada di dalam pikiran bawah sadar kita. Salah satu contoh adalah ketika kita membayangkan seekor kuda yang bersayap (informasi baru), kita sebenarnya membayangkan seekor kuda dan burung (informasi lama).

Proses menulis naratif adalah proses ketika imajinasi kita mengalir mengikuti plot yang sudah dirancang. Apa yang kita tuliskan adalah apa yang kita imajinasikan, yang ketika di dalam kondisi trance terwujud dalam visualisasi mental sebagai produk dari aktivitas pikiran bawah sadar kita. Adalah lebih mudah dan lebih gamblang menulis apa yang dapat kita visualisasikan dibandingkan dengan apa yang kita pikirkan. Dengan kata lain, menulis naratif sebenarnya adalah aktivitas pikiran bawah sadar. Ini tidak berlebihan dan kita lihat sendiri bagaimana proses pikiran bawah sadar penulis naratif dikomunikasikan pada para pembaca. Ketika membaca sebuah novel, seseorang mengalami visualisasi akan apa yang dibacanya. Bahkan, sensasi dan emosi yang terlambang di dalam novel tersebut turut dirasakan oleh pembaca; mereka menangis, tertawa, marah, hanya karena membaca novel (hal ini disebut abreaction). Ini juga berarti membaca naratif pun sebenarnya aktivitas pikiran bawah sadar.

Dengan demikian, kita dapat melihat bagaimana pikiran bawah sadar mempengaruhi proses penulisan naratif (dan juga pembacaannya). Pikiran bawah sadar merupakan pikiran yang kaya dengan informasi-informasi yang dibutuhkan oleh komponen-komponen atau elemen-elemen di dalam sebuah teks naratif, baik itu fiksi maupun yang faktual. Lalu, bagaimana caranya kita menerapkan hal ini di dalam pengajaran menulis naratif? Pada bagian berikut, penulis akan memaparkannya.

\section{Pengajaran Menulis Naratif Berbasis Hipnosis}

Pada bagian ini, penulis menggunakan kata hipnosis dan bukan hypnoteaching. Hal ini berdasarkan pada pemahaman bahwa hipnosis dan hypnoteaching berbeda dari segi aplikasi. Yang akan diterapkan di dalam proses pengajaran menulis naratif ini adalah hipnosis murni, bukan hypnoteaching. Prosedur pelaksanaannya mengikuti prosedur standar hipnosis yang terbagi menjadi tiga bagian yang berisi lima tahapan yakni bagian satu (persiapan) meliputi: (1) preinduksi; bagian trance yang meliputi: (2) induksi, (3) pendalaman; bagian penggalian informasi yang meliputi: (4) sugesti; dan bagian penulisan yang meliputi: (5) post-hipnotik/terminasi.

\section{a. Bagian Persiapan}

Pada bagian ini, kita melakukan tahapan persiapan yang meliputi pre-induksi. Pada tahapan ini, kita menjelaskan kepada para peserta didik tentang pikiran bawah sadar, kondisi trance, dan juga konsep naratif. Kita juga menjelaskan bagaimana pikiran bawah sadar memainkan peranan penting dalam proses penulisan naratif. Kesuksesan dalam tahapan ini merupakan kunci kesuksesan tahapan berikutnya. Kita perlu menjelaskan keberadaan informasiinformasi dalam pikiran bawah sadar yang dapat dimanfaatkan untuk kebutuhan imajinasi dan berkreasi ketika menulis naratif. Dalam contoh ini, kita menyampaikan bahwa mereka akan menulis sebuah pengalaman atau kejadian yang pernah dialami oleh mereka. Setelah itu, kita meminta mereka untuk mempersiapkan alat tulis dan meminta mereka untuk menuliskan salah satu judul untuk mereka sendiri. Judul ini merupakan representasi salah satu pengalaman yang akan mereka tuangkan atau kembangkan menjadi sebuah cerita.

\section{b. Bagian Trance}

Pada bagian ini, kita meminta peserta didik untuk duduk dengan posisi paling nyaman yang mereka 
pilih sendiri. Mintalah mereka untuk memejamkan mata sambil menarik nafas yang dalam dan menghembuskannya, serta lakukan ini beberapa kali. Semakin mereka melakukan ini mereka akan semakin rileks. Mintalah mereka untuk menikmati keadaan mereka saat itu, dan biarkan mereka beristirahat mereka sejenak. Sampaikan kepada mereka dalam konstruksi kalimat positif bahwa semakin mereka merasakan nafas mereka, mereka semakin merasa tenang dan damai. Hindari penggunaan kata tidak, bukan, tidak pernah, dan mengapa. Kata-kata ini akan mengaktifkan pikiran sadar mereka dan karena pikiran bawah sadar tidak mengenali kata-kata berpola negatif. Sehingga, kita perlu mencari padanan kata lain yang positif untuk menggantikan kata-kata negatif tersebut.

Kemudian, mintalah mereka untuk merasakan atau seolah-olah merasakan denyut jantung mereka sendiri. Sampaikan kepada mereka bahwa semakin mereka merasakannya, semakin mereka rileks dan tenang. Perhatikan ekspresi di wajah mereka serta motorik mereka karena ini adalah salah satu tanda keadaan trance. Saat seseorang sudah berada pada kondisi alfa, ekspresi mereka cenderung datar; saat seseorang sudah berada pada kondisi tetha, respon motorik terkesan lambat dan ini yang disebut dengan gejala lethargy. Mintalah mereka untuk menggunakan jari telunjuk atau dengan mengangguk atau menggeleng ketika merespon pertanyaan dari kita. Dan gerakan mereka ini disebut respon ideomotorik. Semakin lambat mereka merespon, semakin dalam kondisi trance mereka.

Kemudian, kita meminta mereka untuk membayangkan mereka berada di suatu tempat yang menyenangkan hati mereka. Pada kondisi ini, pikiran bawah sadar mereka akan langsung memberikan visualisasi (kejelasan visual yang mereka dapatkan tergantung tingkat kedalaman trance mereka) tempat tersebut. Di tempat itu, mintalah mereka untuk membayangkan ada sebuah layar televisi. Mintalah mereka untuk menggerakan jari telunjuk atau mengangguk jika mereka sudah "melihat" tempat itu dan layar televisi itu. Jika mereka belum memberikan respon, maka mintalah mereka untuk lebih tenang dan lebih damai lagi. Jika mereka sudah melihatnya, maka mintalah mereka untuk menampilkan suatu kejadian di masa lalu mereka yang ingin mereka ceritakan. Minta mereka untuk menikmati visualisasi itu dengan jelas. Berikanlah mereka waktu untuk mengalami hal ini.

Ketika mereka sedang berada pada tahapan ini, kita perlu bimbing mereka untuk memperhatikan setiap detil seperti tempat, warna, bentuk, apapun yang bisa ada di dalam visualisas $i$ tersebut. Ini merupakan proses penggalian informasi dari pikiran bawah sadar. Perlu diingat bahwa sebaiknya ini bukan pengalaman yang buruk karena jika yang ditulis atau informasi yang digali adalah pengalaman buruk maka kemungkinan besar akan terjadi abreaction seperti menangis, histeris, dan sebagainya, terutama terhadap pengalaman-pengalaman traumatik. Jika ini terjadi, maka kita segera meminta mereka untuk kembali merasakan tempat yang menyenangkan dan ketika mereka sudah kembali tenang, mintalah mereka untuk mengingat kembali pengalaman indah mereka.

Kemudian, mintalah bagi mereka yang merasa sudah cukup mengingat atau melihat apa yang perlu mereka lihat untuk bersiap-siap untuk bangun. Berikanlah hitungan pada mereka seperti "Saya akan menghitung dari 1 sampai dengan 10, semakin saya menghitung, Anda akan merasa semakin segar dan nyaman. Pada hitungan ke 10 anda akan membuka mata anda dalam keadaan yang sehat, kuat, tenang, senang, dan semua yang anda lihat tadi akan Anda ingat hingga Anda selesai menuliskannya. 1... 2...3.. dan hitunglah sampai 10 sampai mereka membuka mata mereka. 


\section{c. Bagian Penulisan}

Penulis berasumsi bahwa setiap peserta didik kini sudah membuka mata mereka, sudah kembali ke kondisi beta mereka. Kini, mintalah mereka untuk memulai menuliskan cerita mereka itu. Mereka akan menuliskan apapun yang mereka lihat dan satu-satunya kendala pada saat ini adalah struktur naratifnya, dan ini seharusnya sudah diajarkan pada bagian persiapan, yakni bagian konsep naratif.

Pada bagian ini, biarkan para peserta didik untuk menuangkan seluruh pengalaman yang mereka lihat, yang mereka dapatkan kembali, ketika mereka berada di kondisi trance. Dan pada dasarnya, ketika mereka menuliskan hal ini, mereka masih terbayangi oleh visualisasi yang mereka alami. Ini berarti pada dasarnya mereka masih berada pada kondisi trance; mereka berada pada kondisi trance dengan mata terbuka. Inilah sisi terbaiknya, yakni mereka akan begitu kreatif dalam menuangkan cerita ke dalam suatu teks naratif. Setelah mereka selesai menulis naratif mereka, secara otomatis mereka akan keluar dari kondisi trance tersebut.

Ini adalah contoh paling sederhana untuk diterapkan pada kelas menulis naratif. Selain itu, disamping menggali informasi dari pengalaman nyata, para peserta didik juga sebenarnya bisa dimintai untuk berimajinasi untuk membangun cerita. Ini akan membutuhkan waktu yang lebih lama karena mereka harus merangkai satu imajinasi dengan imajinasi lainnya. Meskipun demikian, kita semua pada dasarnya mampu menerapkan hal ini di kelas-kelas menulis dan dengan demikian produk atau karya tulis fiksi peserta didik bisa berkembang. Ketika hal ini sudah seringkali dilakukan, maka ketrampilan menulis mereka akan berkembang karena sudah menjadi kebiasaan yang tertanam di dalam pikiran bawah sadar mereka, seperti sebuah program yang tinggal dijalankan.

\section{Kesimpulan}

Pada dasarnya, proses penulisan naratif (begitu juga dengan proses pembacaannya) adalah proses yang melibatkan aktivitas pikiran bawah sadar yang cukup signifikan. Pikiran bawah sadar menyumbang begitu besar peran dan fungsi kreatif dalam menampilkan informasi atau datadata dalam bentuk visual ketika seseorang berada dalam kondisi trance. Dan ini dapat dimanfaatkan untuk membimbing peserta didik dalam menulis naratif, bahkan dapat kita manfaatkan untuk diri kita sendiri ketika kita ingin menulis naratif. Meskipun demikian, perlu dilaksanakan suatu pengujian empirik terhadap efektifitas serta pengaruh-pengaruh terhadap keterampilan berbahasa yang lain seperti berbicara dan menyimak.

\section{Daftar Pustaka}

Abdul Latif, R. 2013. Pengaruh Metode Hypnoteaching dalam Contextual Teaching and Learning (CTL) terhadap Kemampuan Komunikasi dan Analisis Kritis Siswa Kelas XI IPA di SMA Negeri 5 Yogyakarta. SKRIPSI. Universitas Islam Negeri Sunan Kalijaga Yogyakarta.

Alwasilah, A. C., dan Alwasilah, S. S. 2005. Pokoknya Menulis: Cara Baru Menulis dengan Metode Kolaborasi. Bandung: Kiblat.

Bargh, J. A. dan Morsella, E. 2008. The Unconscious Mind. Perspectives on Psychological Science. Volume 3 - Number 1. p.73-79.

Evans, V. 2000. Successful Writing Proficiency. Express Publishing.

Feez, S dan Joyce, H. 2000. Writing Skills: Narrative and Non-Fiction Text Types. Phoenix Education.

Gunawan, A. 2012. Hypnosis: The Art of Subconscious Communication. Gramedia Pustaka Utama.

Gunawan, A. 2012. Hypnotheraphy: The Art of

Subconscious Restructuring. Gramedia Pustaka Utama.

Hajar, I. 2012. Hypnoteaching: Memaksimalkan

Hasil Proses Belajar Mengajar dengan Hypnoterapi. Diva Press. 
McLeod, S. A. (2015). Unconscious Mind.

Diakses dari

www.simplyp sychology.org/unconscious-

mind.html pada 03/04/2016 22:57.

Nurindra, Y. 2008. The Secret of Stage Hypnosis

Revealed: Membuka Tabir Rahasia Hipnosis

Panggung. (ebook) Indonesian Board pf Hypnotherapy.

Nurindra, Y. 2008. Hypnosis for Dummies: Cara Mudah Belajar Hipnosis. (ebook)

Indonesian Board of Hypnotherapy. 